\title{
CHALLENGES AND OPPORTUNITIES IN THE INBOUND TOURISM OF JAPAN AFTER DISASTER AND PANDEMIC
}

\author{
Rohayati Paidi ${ }^{l}$, Mohd Najmuddin Suki ${ }^{2}$, Md Nasrudin Md Akhir ${ }^{3}$, \\ Geetha Govindasamy ${ }^{4}$, Siti Fatimah Abdul Alim ${ }^{5}$
}

According to the data published by JTB Tourism Research \& Consulting Co., for the period beginning 1990 until 2019, the growth rate of inbound tourism in Japan has shown a steady increase which resulted in an average of $11.5 \%$ every year. This encouraging development was the result of the full-fledged "Inbound Tourism Initiative", campaign launched in 2003, which originally aimed at attracting 10 million foreign tourists to Japan in 2010. However, it is undeniable that there were so many challenges Japan had to overcome alongside that process due to problems that arise out of things beyond control such as natural disasters and epidemics. This article discusses in detail the volatile situation plaguing the inbound tourism industry in Japan. Analyzing from one single perspective that is why people would or would not travel to Japan, this paper seeks to observe how Japan managed to realize the inbound tourism rebound after disasters and epidemics. By employing secondary data analysis, this effort aims to present data about the determinants and factors influencing inbound tourism to Japan from as many countries as possible. This work will then examine in depth the challenges and opportunities that Japan might need to deal with in addressing the impact of COVID-19 on inbound tourism by taking Malaysia as a case study.

Keywords: inbound tourism, COVID-19, perceived risk, push and pull factor, Malaysian tourists

\section{INTRODUCTION}

The rapid development of Japan's inbound tourism prior to COVID-19 was to a large extent the outcome of the government's substantial efforts to attract tourists through extensive relaxation of visa requirements, supported by other favorable developments such as yen depreciation and income convergence overseas. ${ }^{6}$

\footnotetext{
${ }^{1}$ Corresponding Author: Senior Lecturer, Department of East Asian Studies, Faculty of Arts and Social Sciences, University of Malaya, Malaysia. Email: rohayatipaidi@um.edu.my.

${ }^{2}$ Senior Lecturer, HELP University, Kuala Lumpur, Malaysia. Email: mohdns @ help.edu.my.

${ }^{3}$ Associate Professor, Department of East Asian Studies, Faculty of Arts and Social Sciences, University of Malaya, Malaysia. Email: mnasrudi@um.edu.my.

${ }^{4}$ Senior Lecturer, Department of East Asian Studies, Faculty of Arts and Social Sciences, University of Malaya, Malaysia. Email: geethag@um.edu.my.

${ }^{5}$ Research Assistant, Department of East Asian Studies, Faculty of Arts and Social Sciences, University of Malaya, Malaysia. Email: stfatimah49@gmail.com.

${ }^{6}$ Anh Thi Nguyen, “Japan's Inbound Tourism Boom: Lessons for Its Post-COVID-19 Revival,” IMF Working Papers, Vol. 20, No. 169, 2020, pp. 18-19
} 
According to the data published by JTB Tourism Research \& Consulting Co., for the period beginning 1990 until 2019, the growth rate of inbound tourism in Japan has shown a steady increase which resulted in an average of $11.5 \%$ every year. Looking at the number of inbound tourists in 1990, it was merely $1,879,497$ people in total. In 2019 however, the figure has increased to reach 28,257,141 people. The sudden growth of $26 \%$ recorded in 2004 bringing the total number of inbound tourists to nearly 4 million people in that year. Japan continues to receive more than 4 million tourists per year since 2005 until it reached 10 million people for the first time in 2014. A high growth rate surpassing $30 \%$ per year could be observed beginning 2010 until 2015, except for a sudden decrease in 2011 due to the Tohoku Earthquake and Tsunami. This encouraging development in inbound tourism experienced by Japan was the result of the full-fledged "Inbound Tourism Initiative" campaign launched in 2003, which originally aimed at attracting 10 million foreign tourists to Japan in $2010 .^{7}$

Even though Japan is considered as successful in developing its inbound tourism with the purpose of making it comparable to domestic and outbound tourism ${ }^{8}$, it is undeniable that there were so many challenges that Japan had to overcome alongside that process. Problems that arise due to things beyond control such as natural disasters and epidemics are among the challenges that need to be faced by the parties involved with the tourism industry in Japan. In the short run, it has been proved that natural disasters do have significant effects on Japan's inbound tourism demand. Similar to natural disasters, the outbreak of contagious diseases would also affect the demand for inbound tourism in Japan. Despite repeated challenges, Japan has managed to increase the number of tourists to its country to reach 28 million people by 2019 .

This article discusses in detail the volatile situation plaguing the inbound tourism industry in Japan. Analyzing from one single perspective that is why people would or would not travel to Japan, this paper seeks to observe how Japan managed to realize the inbound tourism rebound after disasters and epidemics. By employing secondary data analysis, this effort aims to present data about the determinants and factors influencing inbound tourism to Japan from as many countries as possible. This work will then examine in depth the challenges and opportunities that Japan might need to deal with in addressing the impact of COVID-19 on inbound tourism by taking Malaysia as a case study.

\section{INBOUND TOURISM SURROUNDING DISASTER AND EPIDEMIC}

For the period beginning 1990 until 2020, Japan has experienced six episodes of a major decrease in international tourist arrivals. Of these six episodes, four are related to natural disasters while two are about virus spread. The first episode happened in 1993 when the Hokkaido Earthquake took place. The second episode is from 1995, the year of the Great Hanshin Earthquake. In 2003, the spread of the SARS virus in Japan also witnessed a decrease in tourist arrivals. The fourth episode happened in 2009 when Shizuoka prefecture got hit by an earthquake and the world got hit by the H1N1 virus spread. It is then followed by the 2011 Tohoku Earthquake and Tsunami which brought a huge impact on Japan. For the most recent episode, it happened due to the outbreak of COVID-19 in late 2019. In 2020, Japan recorded a -88\% tourist arrivals in the country. The number of international tourists has collapsed severely since the beginning of the year, with essentially no tourists arriving from April onwards.

During the 1993 Hokkaido Earthquake and 1995 Great Hanshin Earthquake, Asian countries recorded a relatively lower growth rate of inbound tourists in Japan. For example, Thailand recorded a $39.7 \%$ decrease in the number of tourists to Japan. Malaysia also recorded a relatively huge decrease in

\footnotetext{
${ }^{7}$ Akira Soshiroda, "Inbound Tourism Policies in Japan from 1859 to 2003," Annals of Tourism Research, Vol. 32, No. 4, 2005, pp. 1100-1107.

${ }^{8}$ Akira Soshiroda, “Inbound Tourism Policies in Japan from 1859 to 2003,” Ibid., pp. 1108-1109.
} 
the number of inbound tourists of $-33.6 \%$ to Japan. Average tourist data did show positive growth for European tourists to Japan, however, despite these two disastrous events. This includes the United Kingdom (UK) where the percentage of tourists coming to Japan improved from $3.3 \%$ (1992) to $9.2 \%$ in 1993. Despite the increase in growth rate from the UK, the percentage dropped to around half from $16.4 \%$ in 1994 to only 8\% in the following year. People from Africa, Australia, and New Zealand on the other hand seemed not really affected by the catastrophe. For example, there is a $9.7 \%$ increase and merely $0.5 \%$ decrease in the number of African tourists to Japan in 1993 and 1995.

The Great Hanshin Earthquake which occurred in 1995 was known to be the deadliest earthquake since World War II. The casualties numbered 6,434 people. One of the affected areas was Kyoto, the prefecture famous for Japan's tourism economy. Kyoto had been receiving annual foreign tourists of almost 500,000 priors. However, after the disaster, the numbers began to fall below normal. ${ }^{9}$ This correlates with the drop in percentage of inbound tourism's growth rate for most of the countries which can be seen in Table 1. On the contrary, inbound tourism in Japan began to rise in the following year (1996) as positive growth rates were seen for many countries in Asia and Europe. For instance, Hong Kong showed the highest growth rate after the 1995's calamity where the percentage skyrocketed to $111.2 \%$ (1996) from $-42.1 \%$ in 1995 . The same situation goes to Malaysia as well as the number of tourists rose by $36.7 \%$ in one year. In Europe, both the United Kingdom (16.8\%) and Russia (23.5\%) showed positive growth in the post-catastrophe.

Among the episodes related to natural disasters, the 2011 Tohoku Earthquake and Tsunami which hit Japan on March 11, 2011 had the biggest impact with annual tourist numbers arriving in Japan falling to $-35.9 \%$. Spanish tourists who are among the most prominent to Japan seemingly withdrew resulting in a $-62.3 \%$ growth rate. Other countries which showed a similar tendency are Italy (-59.8\%), Austria ($56.1 \%)$, and Germany $(-54.6 \%)$. Most other countries have recorded around $-30 \%$ of growth rate except for Ireland which recorded a positive growth despite a relatively insignificant number. Overall, tourists from Europe have been more reluctant to come and visit Japan during the 2011 disaster. In addition, a declining growth rate is observed for most Asian countries. The percentage of tourists from neighboring countries such as South Korea declined from $70.1 \%$ (2010) to $-38.9 \%$ in 2011 . The number of tourists from India also plummeted by $44.7 \%$ following the 2011 natural disaster that befell Japan.

Damage to accessibility was one of the factors to drastically declining tourist numbers in the same year. ${ }^{10}$ Due to the impact of both earthquake and tsunami, lots of damages were done to the facilities, especially on the Japanese transportation sector. Tokyo's main airports which are the main destinations for most international flights, Narita and Haneda airport were closed at that time. Many international airlines suspended their flights to Japan such as Korean Air, China Southern Airlines, Air India, and many more. ${ }^{11}$ Moreover, according to Japan Immigration Bureau's Narita branch spokesman, Taichi Iseki, the number of foreigners arriving at the Narita airport declined around 60\% in 10 days after the disaster struck Japan. ${ }^{12}$ Besides affecting the flights, the disaster also caused a nuclear incident at the Fukushima Daiichi

\footnotetext{
${ }^{9}$ Nicholas D Kristof, An Ancient City Hopes to Reassure Tourists That It Is Safe to Visit, The New York Times, 24 January, 1995, available at: https://www.nytimes.com/1995/01/24/world/quake-japan-kyoto-ancient-city-hopes-reassure-tourists-thatit-safe-visit.html, accessed on 23 March, 2021.

${ }^{10}$ Lingling Wu, "An Analysis of Inbound Tourist Behavior after the Great East Japan Earthquake,” In 13th Global Forum on Tourism Statistics, 2014.

${ }^{11}$ Centre for Aviation (CAPA), Airports in North-East Japan Affected by Earthquake and Tsunami: Airline Responses UPDATE 1, CAPA, 13 March, 2011, available at: https://centreforaviation.com/analysis/reports/airports-in-north-east-japanaffected-by-earthquake-and-tsunami-airline-responses---update-1-47679, accessed on 23 March, 2021.

${ }^{12}$ Centre for Aviation (CAPA), Japan Crisis Has Major Impact on Regional Travel and Tourism Flows, CAPA, 25 March, 2011, available at: https://centreforaviation.com/analysis/reports/japan-crisis-has-major-impact-on-regional-travel-andtourism-flows-48553, accessed on 23 March, 2021.
} 
Nuclear Power Plant in Fukushima Prefecture. The nuclear leakage issue prompted more visitors to cancel their trip to Japan as it was not safe to travel during this period. This has caused the foreign tourists to be unable to visit Japan for a temporary period after the disaster.

Table 1: Growth Rate of Inbound Tourism in Japan Before, During and After Disaster (\%)

\begin{tabular}{|c|c|c|c|c|c|c|c|c|c|c|c|c|c|c|c|}
\hline Cou & 992 & 1993 & 1994 & 1995 & 1996 & 2002 & 2003 & 2004 & 2008 & 2009 & 2010 & 2011 & 2012 & 2019 & $\begin{array}{l}2020 \\
\text { ( Oct } \\
2020)\end{array}$ \\
\hline ASIA & -3.2 & -13.5 & -4.4 & -11.4 & 28.3 & 20.0 & 5.5 & 30.7 & 8.2 & -11.1 & 30.6 & -36.7 & 66.5 & 9.9 & -87.5 \\
\hline Korea & -0.2 & -5.9 & 8.1 & -10.3 & 23.1 & 15.9 & 21.2 & 13.1 & -9.2 & -39.0 & 70.1 & -38.9 & 30.9 & -27.8 & -92.2 \\
\hline China & 17.2 & -9.2 & -7.2 & 3.8 & 14.9 & 40.5 & -5.2 & 97.6 & 11.9 & 5.7 & 72.7 & -45.5 & 83.0 & 15.5 & -89.9 \\
\hline Taiwan & 10.0 & -6.5 & -3.4 & -12.8 & 28.2 & 8.6 & -11.4 & 41.2 & 0.7 & -27.8 & 24.8 & -23.8 & 53.1 & 2.8 & -86.1 \\
\hline Hong Kon & 18.9 & -16.7 & -3.5 & -42.1 & 111.2 & 12.5 & -10.7 & 19.0 & 28.4 & -18.5 & 13.1 & -29.4 & 34.1 & 3.8 & -84.9 \\
\hline Thailand & -15.1 & -39.7 & -27.6 & -27.9 & 43.7 & 28.3 & 14.8 & 43.8 & 19.9 & -5.3 & 22.1 & -42.6 & 111.8 & 17.5 & -83.7 \\
\hline Singapore & -6.3 & -8.4 & 5.3 & -3.9 & 1.9 & 20.8 & 1.0 & 8.6 & 15.1 & -11.5 & 24.8 & -43.2 & 31.2 & 13.4 & -89.9 \\
\hline Malaysia & -29.9 & -33.6 & -13.6 & 8.8 & 45.5 & 16.1 & 2.0 & 20.1 & 12.5 & -14.2 & 33.1 & -37.4 & 88.9 & 7.5 & -85.2 \\
\hline Indonesia & -7.0 & -9.5 & -10.1 & -18.8 & 27.4 & 17.6 & 23.4 & -4.3 & 5.4 & 2.4 & 28.3 & -36.2 & 100.9 & 2.7 & -83.7 \\
\hline Philippines & -12.0 & -3.8 & 10.6 & 1.1 & -22.0 & 22.3 & 23.5 & 42.9 & -7.5 & -10.4 & 13.6 & -31.1 & 63.4 & 24.2 & -84.2 \\
\hline Vietnam & n.a. & n.a. & n.a. & n.a. & n.a. & n.a. & n.a. & n.a. & n.a. & 6.4 & 31.4 & -33.9 & 77.6 & 27.9 & -90.1 \\
\hline India & -7.1 & -1.7 & -2.6 & -12.0 & 9.4 & 17.5 & -3.3 & 24.6 & 5.0 & -9.5 & 3.0 & -41.7 & 56.4 & 21.5 & -92.9 \\
\hline EUROPE & 1.4 & 0.1 & -3.5 & 0.9 & 9.6 & 19.8 & -2.5 & 23.4 & 10.2 & -3.7 & 10.5 & -38.9 & 49.3 & 22.8 & -88.9 \\
\hline UK & 3.3 & 9.2 & 16.4 & 8.0 & 16.8 & 22.9 & -11.1 & 11.3 & -3.6 & -8.9 & -1.7 & -34.9 & 36.8 & 33.3 & -89.0 \\
\hline France & -1.7 & 6.7 & 7.1 & -8.7 & 2.5 & 9.6 & 1.4 & 20.8 & 14.6 & 4.4 & 51 & -49.7 & 61.1 & 13.3 & -88.7 \\
\hline Germany & 14.7 & -2.5 & 3.7 & -6.7 & 12.9 & 6.9 & -3.5 & 25.9 & 8.2 & 1.4 & 11.7 & -54.6 & 66.8 & 17.1 & -88.7 \\
\hline Italy & 14.7 & -1.4 & -6.7 & -13.6 & 17.2 & 12.9 & -0.5 & 19.9 & 10.8 & 18.1 & 4.0 & -59.8 & 80.7 & 10.2 & -93.2 \\
\hline Russia & -20.5 & 17.5 & -43.8 & -4.2 & 23.5 & 4.1 & 21.1 & 48.3 & 11.4 & -31.2 & 10.6 & -47.0 & 78.6 & 33.2 & -82.1 \\
\hline Spain & -1.0 & -27.0 & -13.1 & 6.8 & 9.9 & 27.0 & -9.2 & 44.8 & 32.4 & 9.2 & 2.2 & -62.3 & 96.0 & 10.1 & -92.5 \\
\hline Sweden & 1.3 & -11.3 & -0.7 & -5.8 & 11.5 & 23.8 & -14.3 & 19.6 & 7.0 & -9.9 & 12.9 & -36.3 & 69.4 & 2.0 & -86.7 \\
\hline Netherland & -1.3 & 8.3 & -3.4 & 15.4 & -8.0 & -5.7 & 16.6 & 32.5 & 14.4 & -4.6 & 7.8 & -42.9 & 46.6 & 13.5 & -90.8 \\
\hline Swiss & 0.3 & -1.9 & 3.8 & -5.0 & 0.3 & 7.0 & 5.1 & 21.6 & 6.6 & 1.3 & 15.6 & -48.1 & 74.7 & 4.3 & -89.8 \\
\hline Belgium & -2.6 & 0.2 & 4.4 & -10.2 & 6.0 & 8.4 & -11.1 & 17.8 & 20.4 & -4.3 & 15.5 & -50.0 & 58.6 & 17.6 & -91.1 \\
\hline Finland & n.a. & n.a. & n.a. & 16.1 & -2.1 & -1.2 & 17.6 & 25.5 & 17.8 & -2.0 & -8.0 & -44.9 & 55.7 & 10.6 & -83.8 \\
\hline Denmark & 38.2 & -16.4 & -3.3 & -4.8 & 11.7 & 24.1 & -9.0 & 13.6 & 3.7 & -5.1 & 14.8 & -35.4 & 29.9 & 17.8 & -86.3 \\
\hline Norway & -2.9 & 20.0 & -9.1 & 7.2 & 6.5 & 9.2 & 14.3 & 15.2 & 12.4 & -5.7 & 3.6 & 0.0 & 15.7 & 12.6 & -86.1 \\
\hline Austria & 5.7 & 0.0 & -1.2 & 0.7 & 8.5 & 6.0 & 3.0 & 19.9 & 2.2 & 19.5 & 5.0 & -56.1 & 52.9 & 17.4 & -88.9 \\
\hline Portugal & n.a. & n.a. & n.a. & n.a. & n.a. & n.a. & n.a. & n.a. & n.a. & -19.3 & 24.7 & -1.1 & -24.4 & 24.0 & -90.7 \\
\hline Ireland & n.a. & n.a. & n.a. & 18.6 & 27.0 & 141.3 & -58.0 & 14.8 & -4.7 & -21.6 & -1.5 & 0.5 & -11.1 & 127.8 & -93.4 \\
\hline OTHERS & 2.5 & -2.8 & 2.4 & 1.8 & 2.0 & 31.7 & -18.0 & 24.3 & 3.6 & -12.2 & 8.8 & -29.8 & 51.8 & 22.3 & -86.1 \\
\hline USA & 2.8 & -8.6 & -5.2 & -1.4 & 9.2 & 9.5 & -15.1 & 27.1 & -3.5 & -4.8 & 1.3 & -30.4 & 39.7 & 15.9 & -88.2 \\
\hline Canada & 17.1 & 5.0 & -0.1 & -2.8 & 13.9 & 6.5 & -3.2 & 16.4 & 4.6 & -7.1 & -0.3 & -40.1 & 43.8 & 14.8 & -86.1 \\
\hline Mexico & 10.8 & -5.2 & -14.0 & -24.9 & 17.0 & 132.4 & -63.5 & 62.4 & -14.9 & -31.4 & 11.3 & -39.6 & 52.1 & 6.1 & -87.5 \\
\hline Brazil & -43.4 & -23.5 & 13.2 & 34.4 & -3.3 & 7.4 & -32.4 & 25.4 & 19.8 & -19.3 & 32.7 & -12.5 & 108.6 & 5.8 & -88.4 \\
\hline Africa & -6.2 & 9.7 & -12.0 & -0.5 & -13.9 & 54.2 & -15.4 & 1.9 & 0.8 & -6.6 & 9.8 & -21.7 & 37.4 & 66.6 & -92.8 \\
\hline Australia & 13.3 & 7.0 & 3.8 & -6.3 & 11.4 & 14.0 & 6.7 & 18.0 & 14.6 & -12.1 & 6.3 & -31.9 & 32.7 & 13.4 & -76.3 \\
\hline $\begin{array}{l}\text { New } \\
\text { Zealand }\end{array}$ & 23.1 & -4.1 & 31.4 & 14.1 & -20.3 & -1.9 & -3.4 & 19.1 & 3.7 & -4.4 & 0.3 & -32.1 & 48.5 & 33.2 & -83.4 \\
\hline
\end{tabular}

Source: Authors' own compilation from various sources

A year after the 2011 Tohoku Earthquake and Tsunami incident, the growth rate percentage for inbound tourism in Japan has begun to show improvement. The tourists from Asia soared overall from - 
$36.7 \%$ to $66.5 \%$ in 2012. Both Indonesia and Singapore have the highest positive growth rate which was about $64.7 \%$ and $69.2 \%$ respectively in a year. Although most of the European countries showed an increase in number, both Portugal $(-24.2 \%)$ and Ireland $(-11.1 \%)$ appeared to be the opposite. The improvement in inbound tourism was because of the initiatives taken by the Japanese government to revive the country's tourism economy after the occurrence of the major disaster in 2011. One of the initiatives was by shifting tourism activity to Okinawa as the island is far from the epicenter of the earthquake and considered safe to travel as it did not possess any threat of radiation from Fukushima prefecture. ${ }^{13}$ The government focused on tourists from neighboring countries such as China. Multiple-entry visas were issued to Chinese tourists to enable them to visit Okinawa for at least one night. ${ }^{14}$ Hence, this resulted in a surge of growth rate for Chinese tourists from $-45.5 \%$ (2011) to $83.0 \%$ (2012). Besides, accurate information related to the potential threat of natural disaster and radiation levels in some parts of Japan were provided on The Japan National Tourism Organization's website to ensure foreigners plan carefully before traveling to Japan.

In early 2003, reports of apparent outbreaks of pneumonia in China, Taiwan, Hanoi, Vietnam, and Hong Kong led the World Health Organization (WHO) to issue a global alert on 12 March 2003. On 15 March 2003, WHO issued a second alert and travel advisory, and named the disease severe acute respiratory syndrome (SARS). Even though Japan experienced the entrance of a SARS-CoV infected person who had traveled to western Japan for a vacation and was later confirmed to be suffering from SARS, Japan with its highly concentrated population has not experienced a domestic spread of SARS. ${ }^{15}$ However, as can be seen in Table 1, Japan received fewer tourists from China, Taiwan, and Hong Kong where the virus widely spread. Also, the major reductions in inbound markets were in travelers from America (Mexico, Brazil \& USA), and some countries in Europe such as Ireland, Sweden and Belgium.

During the 2009 H1N1 virus spread and Shizuoka Earthquake, even though Korea recorded the highest negative growth rate, on average American countries showed a higher decrease in terms of tourist arrival in Japan. The same goes with the situation in 2003 when the SARS outbreak happened, American countries especially Mexico have contributed largely to the reduced number of tourists arriving in Japan. On the other hand, Asian countries like the Philippines, Indonesia, and South Korea have shown a more than $20 \%$ increase in the inbound tourist arrivals in Japan.

Despite the drop in the growth rate during 2009, the inbound tourism showed recovery in the following year especially in Russia and Brazil where the number of incoming tourists to Japan from both countries climbed to $10.6 \%$ and $32.7 \%$ respectively. The Japanese government's effective measures to control the spread of the H1N1 virus have successfully ended the outbreak in the country. The 2009 H1N1 pandemic came to its end in August 2010 when WHO announced the decreasing cases of infection all over the world and became much like any other flu strain. ${ }^{16}$ Thus, tourism activities were resumed in Japan when the threat became low and this led to the increase in inbound tourism. Moreover, other factors such as the strong Japanese yen and expansion of international flights at Narita Airport also contributed to the rise of tourists in Japan in $2010 .{ }^{17}$

\footnotetext{
${ }^{13}$ David Beirman, Making It Safe: Tourism after Japan's Earthquake, The Conversation, 22 February, 2021, available at: https://theconversation.com/making-it-safe-tourism-after-japans-earthquake-5691, accessed on 23 March, 2021.

${ }^{14}$ Liu Jiangyong. Japan Issues Multiple-Entry Visas to Chinese Tourists, People's Daily Online, 20 July, 2011, available at: http://en.people.cn/90001/90776/90883/7446588.html, accessed on 23 March, 2021.

${ }^{15}$ H Nishiura et al., "Modelling Potential Responses to Severe Acute Respiratory Syndrome in Japan: The Role of Initial Attack Size, Precaution, and Quarantine," Journal of Epidemiology \& Community Health, Vol. 58, No. 3, 2004 , pp. $186-91$.

${ }^{16}$ Martin Enserink, WHO Declares Official End to H1N1 'Swine Flu' Pandemic, Science, 11 December, 2017, available at: https://www.sciencemag.org/news/2010/08/who-declares-official-end-h1n1-swine-flu-pandemic, accessed on 23 March, 2021.

17 Yoshitaka Ishikawa, "Impact of the Economic Crisis on Human Mobility in Japan: A Preliminary Note," Belgeo, No. 3-4, 2011, pp. 129-148.
} 
The recent outbreak of the SARS-CoV-2 or much better known as the Coronavirus Disease 2019 (COVID-19) resulted in a collapse of the whole world's tourism economy and Japan was not an exception. The alarming levels of spread and severity of the cases caused the World Health Organization (WHO) to declare COVID-19 as a pandemic on 11 March 2020. The first case of COVID-19 was identified in Wuhan, China in December 2019. Japan confirmed its first case on 16 January 2020 from a 30-year-old resident in Kanagawa Prefecture who had returned from the epicenter of the pandemic, Wuhan, China. ${ }^{18}$ The pandemic has caused the number of foreign tourists to Japan to plunge to more than $-80 \%$ for every country. Due to the strict travel restrictions and lockdown being imposed inside and outside of Japan, people were prohibited from traveling to foreign countries until today. ${ }^{19}$ This was enforced to contain the spread of the Coronavirus in Japan as well as other countries.

Overall, Japan has been taking many initiatives to improve its country's inbound tourism. For instance, under the Koizumi administration which began in April 2001 and lasted until September 2006, the inbound tourism in Japan was emphasized as an important policy for the first time, which later on found its expression in the "Yokoso! Japan" campaign introduced in 2003 and the establishment of the Tourism Agency within the Ministry of Land, Infrastructure, Transport and Tourism in 2009. ${ }^{20}$ However, due to the economic depression after the "Lehman shock" in 2008, influenza fears in spring 2009, the free fall of most currencies against the yen, as well as political problems with China in autumn 2010, the goal to receive ten million visitors from abroad by 2010 has not been achieved. ${ }^{21}$ The catastrophe that happened in March 2011 delayed the target line farther until it was finally achieved in 2014 when the number of inbound tourists reached the 10 million milestones.

Likewise, many people like to travel to Japan as the country has traditionally been perceived as a safe travel destination. However, after the devastating Tohoku earthquake and tsunami hit northeast Japan in 2011, the incident led to the nuclear accident at Fukushima Daiichi and possessed a high threat of radioactive contamination of marine life. This has brought a negative image of Japan as a travel destination and thus became widespread. ${ }^{22}$ The success of post-disaster tourism depends on the role and effective collaboration between stakeholders. Tourism stakeholders can be broadly classified into three types, namely, the public sector (governments and public authorities), the private sector (tourism industries, private enterprises, and businesses), and the third sector (other actors such as non-governmental organizations and communities). ${ }^{23}$

The "White Paper Disaster Management in Japan 2015" is an example of the action taken by the public sector to play their part in the role. The document has been defined by the United Nations International Strategy for Disaster Reduction (UNISDR) as one of the most noteworthy initiatives in the

\footnotetext{
${ }^{18}$ Lisa Schnirring, Japan Has 1st Novel Coronavirus Case; China Reports Another Death, Center for Infectious Disease Research and Policy (CIDRAP), 16 January, 2020, avalable at: https://www.cidrap.umn.edu/news-perspective/2020/01/japanhas-1st-novel-coronavirus-case-china-reports-another-death, accessed on 23 March, 2021.

${ }^{19}$ Kaila Imada, Japan Updates Its Quarantine Rules and Extends Entry Restrictions, Time Out Tokyo, 16 February, 2021, available at: https://www.timeout.com/tokyo/news/japan-extends-travel-restrictions-and-revises-quarantine-rules-020521020521, accessed on 23 March, 2021.

${ }^{20}$ Carolin Funck, "The Innovative Potential of Inbound Tourism in Japan for Destination Development - A Case Study of Hida Takayama," Contemporary Japan, Vol. 24, No. 2, 2012, pp. 121-147.

${ }^{21}$ Carolin Funck, "The Innovative Potential of Inbound Tourism in Japan for Destination Development - A Case Study of Hida Takayama," Ibid., p. 124.

${ }^{22}$ Sung Hee Park, Chi-Ming Hsieh, and Choong-Ki Lee, "Examining Chinese College Students' Intention to Travel to Japan Using the Extended Theory of Planned Behavior: Testing Destination Image and the Mediating Role of Travel Constraints," Journal of Travel \& Tourism Marketing, Vol. 34, No. 1, 2016, pp. 113-131.

${ }^{23}$ Chan Chung-Shing, Kazuo Nozu, and Qinrou Zhou, "Tourism Stakeholder Perspective for Disaster-Management Process and Resilience: The Case of the 2018 Hokkaido Eastern Iburi Earthquake in Japan," Sustainability, Vol. 12, No. 19, 2020, p. 3 .
} 
field of disaster risk reduction and management due to its comprehensive approach to disaster risk reduction (DRS). ${ }^{24}$ Even though the document only briefly mentioned risk--communication to tourists, several offline and online tourist-engagement initiatives such as emergency drills, online English guide regarding safety information in case of an earthquake and/or a tsunami, and mobile Apps that provide disaster alerts and warnings in several languages have been adopted by local authorities within the country. ${ }^{25}$

Furthermore, Jin et al. stressed that information on the impact of a non-political crisis event, provided by relevant authorities, deemed as transparent, scrupulous, and symmetric, is important on tourists' travel decision-making right after a crisis event. Specific to the Chinese outbound market, government-led promotional tourism campaigns at the national level and favorable visa policy have been effective to increase tourist arrival and considered conducive to recovery. For example, right after the Fukushima 2011 nuclear crisis, Japan launched numerous preferential policies in response to the tourism crisis to stimulate the market demand, including new visa policies for Chinese tourists. ${ }^{26}$ Besides that, cultural exports such as anime and manga from Japan to China shapes destination image and attractiveness thus it plays a role in the formation of impact and post-events recovery. ${ }^{27}$

\section{THE MALAYSIAN CASE}

Table 2 shows the number of Malaysian tourists to Japan according to month for the period between 1996 and 2019. It can be seen from the table that Malaysians prefer to visit Japan during school holidays. On average, $18 \%$ of total visitors who went to Japan for a tour did so in December, and $12 \%$ did so in November. Both April (10\%) and June (9\%) were also considered to be popular for travel. The least popular month to go for travel in Japan is August (4\%). In the last 24 years, the size of inbound tourists from Malaysia to Japan has increased more than 14 times with an average of 15\% per year. In 1996, the total number of Malaysian tourists in Japan was 32,389, and it has doubled in 2008 making it reach slightly over 70 thousand. The number then further increased until it increased twofold again within five years to reach a total of 140,484 visitors in 2013. Since then, Japan has witnessed a trajectory of increase in the arrival of tourists from Malaysia with the number doubled from 200 thousand in 2014 to 400 thousand in 2018.

However, it did not always show a positive trend as there were several years in the period which recorded negative growth. The first episode of negative growth happened during 1998 which recorded a $4 \%$ of Malaysian tourist arrivals. The next episode is during 2001 with a -3\% growth rate. The Year 2005 recorded a higher negative growth which was $-35 \%$. In 2009, another episode of negative growth happened with a record of $-14 \%$. Two years later, there was also a negative trend which recorded a $-37 \%$ growth.

All the negative trends highlighted on the table can be related to four types of events namely, changes in the exchange rate, man-made disasters, natural disasters, and virus outbreaks. The 1998 case was due to the appreciation of the Japanese Yen which suddenly increased the rate to 0.034 at the end of January and 0.030 at the end of February 1998. The rate has never surpassed 0.030 before as far as the available data is concerned. With the assumption that people begin preparing for travel a month ahead, we

\footnotetext{
${ }^{24}$ Aliperti Giuseppe, and Ana Maria Cruz, "Risk Communication to Tourists: Towards the Definition of a Research Agenda for a More Effective Disaster Preparedness in Japan," Almatourism, Vol. 9, No. 17, 2018, p. 2

${ }^{25}$ Giuseppe, and Cruz, "Risk Communication to Tourists: Towards the Definition of a Research Agenda for a More Effective Disaster Preparedness in Japan," Ibid., p. 3.

${ }^{26}$ Xin (Cathy) Jin, Mingya Qu, and Jigang Bao, "Impact of Crisis Events on Chinese Outbound Tourist Flow: A Framework for Post-Events Growth,” Tourism Management, Vol. 74, 2019, pp. 334-344.

27 Jin, Qu, and Bao, "Impact of Crisis Events on Chinese Outbound Tourist Flow: A Framework for Post-Events Growth," Ibid., pp. 338-340.
} 
can see that when the exchange rate began to plump at the end of December 1997 making it rose to 0.029 from 0.027 in November 1997, the number of Malaysian tourists went to Japan in February 1998 suddenly fall to less than half of the previous year. The positive trend only resumed in May 1998 after the exchange rate started showing a sign of Yen depreciation in March 1998. However, it was not long before the exchange rate resumed to rise to over 0.031 in October 1998 which witnessed another episode of decrease in the number of Malaysian tourists going to Japan which continued until January 1999. This confirms the argument that in the long run, tourist income, as well as relative price movements, have a significant impact on the total number of tourist arrivals from all country groups to Japan. ${ }^{28}$

Table 2: Number of Malaysian Tourists to Japan

\begin{tabular}{|c|c|c|c|c|c|c|c|c|c|c|c|c|c|c|}
\hline & Jan & $\overline{F e b}$ & Mar & $\overline{\mathrm{Apr}}$ & May & Jun & Jul & Aug & Sep & $\overline{\mathrm{Oct}}$ & Nov & $\overline{\text { Dec }}$ & Total & $\begin{array}{c}\text { Growth } \\
\text { Rate }\end{array}$ \\
\hline 1996 & 4 & 840 & 1,554 & 254 & 83 & 87 & 308 & 166 & 482 & 037 & 4,694 & 080 & 2389 & n.a. \\
\hline 1997 & 02 & 160 & 2,331 & 4,375 & 2,825 & $\begin{array}{l}6,059 \\
\end{array}$ & 1,697 & 1,485 & 2,279 & 2,861 & 4,359 & 6,998 & 39,531 & $2 \%$ \\
\hline 1998 & 637 & 1,270 & 1,965 & 3,718 & 3,128 & 5,738 & 1,665 & 1,983 & 1,836 & 2,779 & 3,488 & 6,672 & 37,879 & $4 \%$ \\
\hline 1999 & 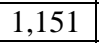 & 3,411 & \begin{tabular}{|l|}
3,294 \\
\end{tabular} & 3,509 & 3,443 & 6,902 & 2,064 & 1,873 & 2,540 & 2,862 & 4,877 & 7,461 & 43,387 & $5 \%$ \\
\hline 2000 & 4 & 3,402 & 3,311 & 4,849 & 3,512 & 5,977 & 1,892 & 1,519 & 2,313 & 3,142 & \begin{tabular}{|l|l|}
4,877 \\
\end{tabular} & 9,517 & & $5 \%$ \\
\hline 2001 & 13 & 1,629 & 3,322 & 4,536 & 3,979 & 6,160 & 2,319 & 1,766 & 2,108 & 2,219 & 4,488 & 8,001 & 44,240 & $-3 \%$ \\
\hline 2002 & 348 & 3,711 & 4,517 & 4,870 & 4,446 & 4,447 & 2,257 & 1,934 & 2,446 & 3,587 & 7,268 & 10,552 & 51,383 & $16 \%$ \\
\hline 20 & & 2,632 & 4,216 & 2,219 & 1,620 & 4,971 & 3,234 & 2,718 & 4,952 & 5,101 & \begin{tabular}{|l|l|}
6,998 \\
\end{tabular} & 11,500 & 0 & $2 \%$ \\
\hline 2004 & 4, & 1,887 & 4,646 & 5,941 & 4,863 & 8,391 & 3,385 & 2,727 & 3,231 & 3,773 & \begin{tabular}{|l|}
8,479 \\
\end{tabular} & 11,173 & 62,930 & $20 \%$ \\
\hline 2005 & 1,125 & 2,595 & 4,599 & 5,534 & 3,897 & 2,600 & 1,830 & 1,903 & 2,513 & 4,247 & 3,913 & 5,881 & 40,637 & $g^{2}$ \\
\hline 2006 & 3,80 & 1,417 & \begin{tabular}{|l|}
3,999 \\
\end{tabular} & 7,084 & 3,743 & 2,721 & 2,858 & 2,204 & 2,408 & 5,876 & 4,683 & 8,403 & 49,197 & $21 \%$ \\
\hline 2007 & 211 & 4,265 & 5,610 & 7,555 & 5,406 & 2,966 & 3,129 & 2,517 & 2,732 & 7,046 & 7,078 & 11,036 & 62,551 & $27 \%$ \\
\hline 2008 & 008 & 5,705 & 6,586 & 10,024 & 7,570 & 3,007 & 3,956 & 2,616 & 4,619 & \begin{tabular}{|c|}
6,824 \\
\end{tabular} & \begin{tabular}{|l|}
6,301 \\
\end{tabular} & 11,139 & 70,355 & $12 \%$ \\
\hline 2009 & 4,212 & 1,936 & 5,647 & 6,905 & 3,555 & 2,856 & 2,882 & 2,639 & 4,657 & 5,279 & 7,014 & 12,774 & 60,356 & $14 \%$ \\
\hline 2010 & 2,174 & 5,797 & 8,386 & 8,850 & 7,231 & 5,668 & 5,620 & 2,414 & 5,359 & 5,577 & 7,857 & 15,375 & 80,308 & 33 \\
\hline 2011 & 142 & 6,528 & 3,334 & 822 & 1,704 & 2,506 & 3,327 & 3,070 & 4,650 & 3,866 & $4,8,887$ & 11,476 & 50,312 & $-37 \%$ \\
\hline 2012 & 6,501 & 4,623 & 8,161 & 9,313 & 9,778 & 5,970 & 5,103 & 5,375 & 5,374 & 7,802 & 12,001 & 15,029 & 95,030 & $9 \%$ \\
\hline & 4, & 8,558 & 9,820 & 11,958 & ,994 & 6,891 & 7,292 & 7,968 & 7,758 & 14,452 & 22,876 & 26,077 & & \\
\hline 201 & 11,455 & 241 & 19,286 & 22,095 & 544 & 14,179 & 13,798 & 6,551 & 12,060 & 20,261 & 24,339 & 37,089 & 211,898 & $51 \%$ \\
\hline 2015 & 9,337 & 16,968 & 23,689 & 26,348 & 22,289 & 15,694 & 17,216 & 9,162 & 17,229 & 24,953 & 35,864 & 48,056 & 266,805 & $26 \%$ \\
\hline 2016 & 16,726 & 26,948 & \begin{tabular}{|l|l}
34,027 \\
\end{tabular} & 34,968 & 3,012 & 18,466 & 22,162 & 12,405 & 21,773 & 33,050 & 40,950 & 61,047 & 355,534 & $33 \%$ \\
\hline 2017 & 31,524 & 363 & 4,418 & 39,801 & 2,631 & 27,595 & 18,303 & 18,023 & 22,000 & 35,377 & 48,746 & 62,327 & 399,108 & $12 \%$ \\
\hline 2018 & 27,605 & 32,519 & 188 & 45,664 & 165 & 3,317 & 19,855 & 5011 & 22,195 & 35,076 & 51,894 & 65,118 & 426,507 & \\
\hline 2019 & 27,893 & 33,488 & \begin{tabular}{|l|}
45,887 \\
\end{tabular} & 42,857 & 39,431 & 27,185 & 19,890 & 16,173 & 23,871 & 45,071 & 61,118 & 75,655 & 458,519 & $8 \%$ \\
\hline rage & $5 \%$ & $6 \%$ & $8 \%$ & $10 \%$ & $8 \%$ & $9 \%$ & $5 \%$ & $4 \%$ & $6 \%$ & $8 \%$ & $12 \%$ & $18 \%$ & & $15 \%$ \\
\hline
\end{tabular}

Source: Authors' own compilation from various sources

Beginning September 2001 until six months after that, there was another episode of minus growth in Malaysian tourists' arrival in Japan. The biggest event that occurred at that time was the September 11 terrorists attack on New York's World Trade Towers. When the SARS virus spread in 2003, it also affected the number of Malaysian tourists who went to Japan. This negative growth only lasted for four months before it revived again in June 2003. Two years later, in 2005, Japan experienced another decrease in inbound tourists from Malaysia. This time around, it reached the lowest number of tourists recorded in June every year. In the previous year, 8,391 tourists went to Japan in June, but in 2005 the number was only 2,600. The positive trend resumed four months later in October 2005. What happened during that year was the discovery of the first case of the H5N2 virus on a chicken farm in Jōsō, Ibaraki. In 2009,

\footnotetext{
${ }^{28}$ Anh Thi Nguyen, “Japan’s Inbound Tourism Boom: Lessons for Its Post-COVID-19 Revival,” Ibid., p. 16.
} 
there was also a decrease in the number of Malaysian tourists in Japan. This episode began in February 2009 and lasted until July the same year. The year 2009 is the year of the Shizuoka earthquake and H1N1 virus outbreak. During the 2011 Tohoku Earthquake and Tsunami, a huge decrease was recorded between March and July which resulted in a total of $-37 \%$ growth for that year.

In the short run, natural disasters and virus outbreaks had a broad-based impact on tourist arrivals from all source markets. ${ }^{29}$ Jin et al. suggested that the negative impact of natural disasters and health hazards on tourism is short-lived - usually no more than three months where the general earthquake impact is often limited to the earthquake-struck area and may not often lead to a significant reduction in the overall number of tourists to a country, provided other tourist resources/destinations within the country are not affected. However, it is not true in the case of Malaysian as it took between four to six months to rebound the tourism activities in the affected country. ${ }^{30}$

\section{CHALLENGES: PERCEIVED RISK AND BEHAVIOR AFTER DISASTER}

Yang and Nair defines perceived risk as an individual's subjective assessment of the real risk while the real risk is the amount of risk which exists at that moment given the application of safety controls. ${ }^{31}$ Meanwhile, Dickson and Dolincar argued that a perceived risk is seen as a hurdle to attracting tourists and the managerial aim is to reduce it to increase sales. ${ }^{32}$ Various objective factors contribute to the tourists' risk perception. ${ }^{33}$ Other scholars divided such factors into natural factors (e.g. natural disasters) and artificial factors (e.g. epidemic diseases). ${ }^{34}$ Meanwhile Cheung, Takashima, and Hyungjun named natural disasters as environmental risks and life-threatening diseases as a health risk. ${ }^{35}$ They includes natural disasters into the catastrophe risk. They also combined earthquakes, tsunamis, flash floods, financial crisis, and significant changes in the exchange rate as natural disasters and financial risk, while putting epidemic diseases as a public health risk. In addition, all these scholars listed eight risks that may derive from the event of natural disasters and epidemics namely personal risk, health risk, value risk, moral hazard, social risk, time risk, convenient risk, and crime risk. Polyzos, Samitas, and Spyridou confirmed in their study that there is a certain correlation between the level of tourism risk perception, destination satisfaction, and the impact of natural disasters. ${ }^{36}$ Alongside these perceived risks related to natural disasters and epidemics, tourists also build several other perceived risks based on various objective factors. Among them are

\footnotetext{
${ }^{29}$ Anh Thi Nguyen, “Japan’s Inbound Tourism Boom: Lessons for Its Post-COVID-19 Revival,” Ibid., p. 17.

30 Jin, Qu, and Bao, "Impact of Crisis Events on Chinese Outbound Tourist Flow: A Framework for Post-Events Growth," Ibid., p. 339

${ }^{31}$ Elaine Chiao Yang, and Vikneswaran Nair, "Tourism at Risk: A Review of Risk and Perceived Risk in Tourism," AsiaPacific Journal of Innovation in Hospitality and Tourism, Vol. 3, No. 2, 2014, pp. 239-259.

32 Tracey Dickson, and Sara Dolnicar, "No Risk, No Fun: The Role of Perceived Risk in Adventure Tourism," Research Online, 2004, available at: http://ro.uow.edu.au/commpapers/246, accessed on 23 March, 2021.

${ }^{33}$ Fangnan Cui et al., "An Overview of Tourism Risk Perception,” Natural Hazards, Vol. 82, No. 1, 2016 , pp. $643-658$.

${ }^{34}$ Lingling Wu, “An Analysis of Inbound Tourist Behavior After the Great East Japan Earthquake,” Ibid.

35 Catherine Cheung, Miki Takashima, Hyungjung (Helen) Choi, et al., "The Impact of COVID-19 Pandemic on the Psychological Needs of Tourists: Implications for the Travel and Tourism Industry," Journal of Travel \& Tourism Marketing, Vol. 38, No. 2, 2021, pp. 155-166.

36 Stathis Polyzos, Aristeidis Samitas, and Anastasia Ef. Spyridou, "Tourism Demands and the COVID-19 Pandemic: An LSTM Approac,” Tourism Recreation Research, 2020, available at: https://doi.org/10.1080/02508281.2020.1777053, accessed on 23 March, 2021.
} 
political risk, plan risk, property risk $^{37}$, financial risk, functional risk, personal risk, social risk, time risk, performance risk, health risk, convenient risk and facilitate risk. ${ }^{38}$

Wu suggested three reasons each as to why Chinese and South Korean tourists would or would not travel to Japan after the earthquake. ${ }^{39}$ As for the former, it consists of accessibility improvement, information communication and internal willingness. While for the latter, it could be summarized as accessibility damage, internal worry and external events. Wu also found that Chinese tourists who possess higher income are less likely to cancel their trip after the earthquake. Meanwhile, tourists from South Korea who have higher education levels are less likely to cancel their trip after the earthquake. Thus, the similar study also noticed that tourists with more travel experience to Japan are less likely to cancel the trip after the disaster. Lastly, Wu also identified that people who have a higher perception that "the majority of Japan was directly affected by the earthquake", "it was not safe to travel to Japan because of the aftershock", and "food in Japan has been polluted by nuclear leakage" are more likely to cancel their trip after the 2011 Tohoku Earthquake and Tsunami disaster. ${ }^{40}$

Meanwhile, Handler explores the effect of the 2011 Tohoku Earthquake and Tsunami disaster on the travel intention and change in behavior of Taiwanese travelers and ends up defining her respondents into five clusters. ${ }^{41}$ The first cluster consists of those who are strongly worried about traveling to Fukushima and its surrounding prefectures as well as to the area affected by the Tsunami and also concerned about eating Japanese cuisine and buying Japanese products. The second cluster is made up of travelers who do not alter their travel habits except seeking more information on the destination than usual and having high respect towards the Japanese who endured the Fukushima incident and tsunami. The third cluster consists of people who do not refrain from traveling to Japan, but they are concerned about their health and showing this by their intention to ask for the origin of food, being careful what to touch and wearing a mask during their visit. The fourth cluster which locates the majority of Taiwanese travelers to Japan consists of those who will not change their travel behavior or even seek more information before visiting. The fifth cluster locates a group of people who seem to be concerned about traveling to Japan as a whole, and not only to the affected areas. They will most likely prefer an alternative travel destination until they feel safe again to visit Japan. ${ }^{42}$

To put it all together, Japan has been dealing with natural disasters and life-threatening diseases since a long time ago. Though natural disasters, epidemic diseases, and financial risk are considered to be the perceived risk of the country, there is also another perceived risk developed by the tourists themselves based on the status of their living condition along with other external matters such as their home country's situation. The perceived risk has affected tourists' behavior when they travel to Japan. The major catastrophes and incidents have caused the tourists to become much more aware of their surroundings. Some tourists hesitated to travel to Japan after the occurrence of disaster and epidemic/pandemic while the others continued to visit while taking safeguard measures. They become very health conscious and try to avert getting sick by protecting themselves by wearing masks and avoid going to places with high risk

\footnotetext{
${ }^{37}$ Gagan Deep Sharma, Asha Thomas, and Justin Paul, "Reviving Tourism Industry Post-COVID-19: A Resilience-Based Framework," Tourism Management Perspectives, Vol. 37, January 2012, available at: https://doi.org/10.1016/j.tmp.2020.100786, accessed on 23 March, 2021.

38 Catherine Cheung, Miki Takashima, Hyungjung (Helen) Choi, et al., "The Impact of COVID-19 Pandemic on the Psychological Needs of Tourists: Implications for the Travel and Tourism Industry," Ibid., p. 157.

${ }^{39}$ Lingling Wu, "An Analysis of Inbound Tourist Behavior After the Great East Japan Earthquake," Ibid.

${ }^{40}$ Ibid.

${ }^{41}$ Isabell Handler, "The Impact of the Fukushima Disaster on Japan's Travel Image: An Exploratory Study on Taiwanese Travelers," Journal of Hospitality and Tourism Management, Vol. 27, June, 2016, pp. 12-17.

${ }^{42}$ Handler, "The Impact of the Fukushima Disaster on Japan's Travel Image: An Exploratory Study on Taiwanese Travelers," Ibid., p. 14.
} 
whenever they visit the country. Although not much information was found for tourists besides Asia, the given data regarding tourists from China, South Korea, and Taiwan have provided overviews of the perceived risk owned by the tourists and their behavior towards Japan during the post-disaster period.

\section{OPPORTUNITIES: PUSH AND PULL FACTORS}

This section will discuss the motivation behind inbound tourism in Japan that could counterbalance the perceived risk occurred due to natural disasters and epidemic. In tourism fields, motivation can be divided into push and pull factors. Push factors are internal forces within the person, on the other hand, pull factors are external forces of destination attributes. It has been noted that push factors drive people to travel while pull factors facilitate destination choices. ${ }^{43}$ Existing studies suggest common push factors such as escape, novelty, social interaction, and prestige while as for the pull side, they confirm factors such as 'social opportunities and attractions', 'natural and cultural attractions', 'physical amenities and facilities', and 'nightlife and ambiance' as important for destination choice. ${ }^{44}$ It should be noted however, that it is often difficult to discern which factors operate at any one time and in some cases, there may be several factors operating in parallel. ${ }^{45}$

Shapoval et al looked into the differences between first-time visitors and repeat visitors to the Kansai area of Japan and found that first-time visitors were interested in sightseeing, while repeat tourists were more involved and interested in participating in events. ${ }^{46}$ Cheung, Takashima, Choi, et al concluded in their study that the main motivation for a visitor's future return to Japan is not driven by experiences they had during the previous visit but rather by experiences they want to have when they return, such as Japanese hot springs or immersing themselves in the beauty of nature. Furthermore, experiencing Japanese food appears to remain the main attraction across all segments as a common denominator to attract all different groupings. ${ }^{47}$

Handler analyzed the push factors on why Chinese and Taiwanese students visit Japan using five motivational factors namely knowledge, prestige, enhancement of human relationships, relaxation, and novelty. Among these factors, she found that Chinese students are more likely to come and visit Japan to enhance their knowledge especially on trying Japanese food, and to seek novelty as in finding thrills and excitement. On the other hand, Handler used expenditures, attractions and natural environment as pull factors representing the destination attractiveness of Japan. Overall, Chinese students put expenditures (e.g. opportunities to eat at authentic Japanese restaurants, experiencing the nightlife, and shopping) as the most important factors when deciding to travel to Japan. ${ }^{48}$

Park et al. (2017) stressed that the country's image has a significant impact on attitude as well as the subjective norm and perceived behavioral control, which influence Chinese students' intention to visit Japan. Among the strongest country's image of Japan held by Chinese students are appealing local cuisine

\footnotetext{
${ }^{43}$ A F Fithriyah et al., “Tourists' Attitude Affecting Consumption Behavior for Sustainable Satoyama Tourism: A Comparison between Domestic and International Tourists," IOP Conference Series: Earth and Environmental Science, Vol. 501, 2020, p. 012030.

${ }^{44}$ Girish Prayag and Chris Ryan, “The Relationship between the 'Push' and 'Pull' Factors of a Tourist Destination: The Role of Nationality - an Analytical Qualitative Research Approach,” Current Issues in Tourism, Vol. 14, No. 2, 2011, pp. 121-143.

${ }^{45}$ Seongseop Kim, Bruce Prideaux, and Dallen Timothy, "Factors Affecting Bilateral Chinese and Japanese Travel," Annals of Tourism Research, Vol. 61, 2016, pp. 80-95.

${ }^{46}$ Valeriya Shapoval et al., "Data Mining in Tourism Data Analysis: Inbound Visitors to Japan," Journal of Travel Research Vol. 57, No. 3, 2017, pp. 310-323.

47 Catherine Cheung, Miki Takashima, Hyungjung (Helen) Choi, et al., "The Impact of COVID-19 Pandemic on the Psychological Needs of Tourists: Implications for the Travel and Tourism Industry,” Ibid., p. 158.

${ }^{48}$ Handler, "The Impact of the Fukushima Disaster on Japan's Travel Image: An Exploratory Study on Taiwanese Travelers," Ibid., p. 15.
} 
and good places for shopping. ${ }^{49}$ This further confirms the findings by Suzuki (2009) discussed above. However, in their study, Ugur and Akbiyik also noted that travel constraints such as language barrier, potential radiation contamination, and anti-Japanese sentiment play the role as factors that hinder the intentions to travel to Japan among Chinese college students. ${ }^{50}$

Separately, Jin, Qu, and Bao studied the bilateral tourism flows between Japan and China beyond economic factors by considering the background role of some interrelated issues including shared history, occupation, diplomacy, nationalism, socio-cultural and contemporary events and how they may generate significant negative impacts on tourism flows when unexpected diplomatic disputes emerge. For example, They found that the number of Chinese visitors to Japan during the period 2010-2014 shows a sharp drop during the period of the Senkaku/Diaoyu islands dispute with mainland Chinese tourists' arrivals in Japan decreasing by an average of $28 \%$ to August 2013. ${ }^{51}$

$\mathrm{Xu} \&$ Tavitiyaman (2016) examines factors that drive traveling youths from Hong Kong to Japan and found that cheap currency rate, airline promotion, no visa application requirement, efficient transportation, to escape and try new things, to travel with friends, to visit friends, to travel with family, having received recommendations and positive words of mouth, cleanliness and safety are among the push factors mentioned. On the other hand, the pull factors that attract Hong Kong young tourists to visit Japan can be divided into three categories namely 'natural wonders, man-made attractions and events', 'traditional culture' and 'the hospitality and shopping opportunities. With regards to the first category of pull factors, examples given are snow at Hokkaido, red autumn leaves at Kyoto, sunshine and beach at Okinawa, volcanoes, hot spring, Disneyland, Universal Studios, Fuji-Q Highland, Tokyo tower, noodle museum, ghost house, to visit areas related to disasters, to spectate sports games, horse racing and concerts. For the second category, fresh and traditional food, authentic Japanese food and cuisine, cartoons, temples, to try Kimono are among the examples given. Lastly, regarding hospitality and shopping opportunities, Hong Kong youth pay attention to the value for money, special, reliable and trustworthy products and national brands, the friendliness and politeness of Japanese people, the better hospitality services, and the uniqueness of tatami and capsule hotels. ${ }^{52}$

Nuraeni et al., in their study on Indonesian youth tourists found that all the youth, regardless of their gender, age, and occupation only consider their income in choosing their international trip destination. They also noticed that the respondents prefer to go on an international trip to a place that has warm and friendly local people, spend their expense to enjoy the sightseeing, to see local specificity. ${ }^{53}$

Nevertheless, all these authors generally assessed the competitiveness of Japan, South Korea and China in accommodating the preferences of Malaysian Muslim tourists and noticed that 'access to Muslim culture' was perceived to be the second most influential factor when potential Muslim tourists select an overseas destination. In short, Japan was perceived as having a better destination brand than China except in the case of 'access to Muslim culture'. Malaysian Muslim tourists also perceived that Japan was more favorable than Korea and China in terms of being emotional, familiar, peaceful, and exciting.

\footnotetext{
${ }^{49}$ Oxford Analytica, "Pandemic Damage to Japan's Tourism Sector will Linger," Expert Briefings- Oxford Analytica, 2020, available at: https://doi.org/10.1108/OXAN-DB255140, accessed on 23 March, 2021.

50 Naciye Guliz Ugur, and Adem Akbiyik, "Impacts of COVID-19 on Global Tourism Industry: A Cross-Regional Comparison," Tourism Management Perspectives, Vol. 36, October 2020, available at: https://doi.org/10.1016/j.tmp.2020.100744, accessed on 23 March, 2021.

51 Jin, Qu, and Bao, "Impact of Crisis Events on Chinese Outbound Tourist Flow: A Framework for Post-Events Growth," Ibid., p. 341.

52 Jing Xu, and Pimtong Tavitiyaman, "Why Do Hong Kong Young People like to Visit Japan? An Exploratory Study," Advances in Hospitality and Tourism Research, Vol. 4, No. 1, 2016, pp. 17-25.

${ }^{53}$ Shimaditya Nuraeni, Arlavianyssa Pradiva Arru, and Santi Novani, "Understanding Consumer Decision-Making in Tourism Sector: Conjoint Analysis," Procedia - Social and Behavioral Sciences, Vol. 169, 2015, pp. $312-317$.
} 
You et al. identified the top five travel push factors for the United Kingdom namely 'going places I have not visited before', 'being together as a family', 'increase one's knowledge about places, people and things', 'visit friends and relatives', and 'escaping from the ordinary'. As for the pull factors, UK tourists put primary importance on outstanding scenery, pre-trip information, destination infrastructure (convenience of transportation), environmental quality (safety and hygiene) and the opportunities for socializing and interacting with people provided by the destination of choice. ${ }^{54}$

Jin, Qu, and Bao found that Canadian students put similar importance to obtaining knowledge and novelty when considering international travel. Among the top reasons why Canadian students come and visit Japan are to find thrills or excitement, to visit historical and cultural sites and to experience a different lifestyle. Besides that, Canadian students are also likely to visit Japan to meet Japanese people and make new friends. From the viewpoint of Canadian students, old temples and shrines, Japanese gardens, sumo, geisha, karaoke and onsen are the most attractive attributes of Japan as a tourist destination. ${ }^{55}$

Tkaczynski et al. identified Australian students' activity preferences, perceived physical risk and interest in Japan as a vacation destination. They found in their study that exploring big cities which can constitute sightseeing and shopping, snowboarding/skiing, exploring cultural activities such as visiting historical sites including shrines and temples, experiencing traditional Japanese customs such as tea ceremony and kimono, and attending cultural events related to anime and music are among the motivation shared by Australian students to visit Japan. ${ }^{56}$

Hara argues that even though Japan is surely perceived to be unique and attractive, not many actually decide to travel, at least from the USA. Hara (2013) identified that those who have never traveled to Japan are more prone to a perceived fear of language barriers thus hindering their motivation to visit Japan. Data shows that those who have never traveled to Asia or Japan tend to consider Japan as one of the alien Asian countries with strange and unfamiliar languages, customs and cultures. ${ }^{57}$ Conversely, those who study Japanese are more likely to receive the intended effects of the "Yokoso! Japan" campaign and more likely to visit Japan anyway.

Noh \& Vogt studied the correlation between information sources and perceived risk imagined by European-Americans and found that information from cultural experiences, for example art museums, restaurants, concert halls, and cultural courses, had the highest correlation with the respondents' cognitive image of Japan. Cognitive image refers to the beliefs and knowledge about destination attributes. Noh \& Vogt (2013) also suggest that books and movies were more highly related to the perceived risk of vacationing in Japan. ${ }^{58}$

As a matter of fact, push and pull factors as listed in previous research create opportunities for Japan to counterbalance the perceived risk from both natural disasters and epidemic/pandemic in the country. By push factors, most of the tourists, especially the youngsters intend to visit Japan to gain new knowledge on the country's culture and take part in activities that make them escape from their comfort zone. Another reason for them to visit Japan is to seek new social interaction and broaden their connection

\footnotetext{
${ }^{54}$ Xinran You et al., "A Cross-Cultural Comparison of Travel Push and Pull Factors," International Journal of Hospitality \& Tourism Administration, Vol. 1, No. 2, 2000, pp. 1-26.

${ }_{55}$ Jin, Qu, and Bao, "Impact of Crisis Events on Chinese Outbound Tourist Flow: A Framework for Post-Events Growth," Ibid., p. 340.

56 Aaron Tkaczynski, Hayato Nagai, and Sharyn R Rundle-Thiele, "Australian Students' Activity Preferences, Perceived Physical Risk and Interest in Vacationing in Japan," Journal of Vacation Marketing, Vol. 24, No. 4, 2017, pp. 355-370.

57 Tadayuki Hara, "Perception of Language Barriers or Prior Visit Experience Affect Likelihood of Visiting a Country? Empirical Analysis of Residents in the United States of America about Japan as a Tourism Destination," Waseda Global Forum, Vol. 10, 2013, pp. 391-407.

${ }^{58}$ Jeonghee Noh, and Christine Vogt. "Modelling Information Use, Image, and Perceived Risk with Intentions to Travel to East Asia." Current Issues in Tourism 16, No. 5, 2013, pp. 455-76.
} 
with the local people. Apart from that, through pull factors, the Japanese government provided many tourism facilities to increase inbound tourism in Japan. For instance, the development of sight-seeing attractions fusing with both traditional and modern elements, distinctive food culture, hospitality, and duty-free shopping has managed to invite many tourists from all over the world to Japan. Moreover, Japan also promotes dark tourism to draw tourist's attention towards places that were damaged by disasters and tragedies. This will create a sense of inquisitiveness among the tourists to know more about the history and current condition of the affected areas. It is also seen that both push and pull factors correlate with each other, especially when it involves disputes on diplomatic relations which will strike Japanese tourism. Hence, motivation such as these two factors is important in reviving Japan's inbound tourism in the postdisaster period. Despite most of the past research focused on youth's perspective on traveling to Japan, not much information was collected from older generations, particularly the seniors on their viewpoint choosing Japan as a travel destination.

\section{COVID-19: CHALLENGES OR OPPORTUNITIES?}

Despite the initiatives and efforts taken by the tourism stakeholders to revive the industry and businesses, they cannot escape the various challenges accompanying the process. Lin, Kelemen and Richard suggested five challenges of disaster tourism namely fiscal sustainability, dilemma of municipality, decrease of assistance, harmful rumor and city marketing. ${ }^{59}$ One problem highlighted by Gossling, Scott and Hall is the aging situation in Japan. When the guesthouses in Tohoku got hit by tsunami, the fisherman's families who run the side businesses hesitate to reconstruct the facilities because they require large investment besides there is no guarantee that there will be successors who can take over these side businesses. ${ }^{60}$ Such internal issues which undeniably bring challenges to the recovery of Japan's inbound tourism are beyond the scope of this study. This final section will only focus on the possibility of recovery of inbound tourism in Japan post COVID-19 based on the case study on tourists from Malaysia.

An online random sampling survey has been conducted among Malaysians which resulted in the data collected from 245 respondents. Table 3 shows the breakdown of the respondents according to age, gender, marital status and monthly income as well as their intention to travel abroad after the COVID-19. Overall, $75 \%$ of the respondents showed intention to go travel overseas while only $25 \%$ of them said "no". To summarize, we find that people in the 55-59 years old age bracket, unmarried and/or earn more than RM7,000 monthly income the most receptive towards the idea of traveling abroad after the pandemic. Conversely, respondents within the 30-34 years old age bracket, married with no children and/or earning less than RM2,500 monthly exhibit overall tendency to dismiss traveling abroad after the COVID-19 pandemic. In terms of gender, male respondents demonstrate a greater inclination towards the activity as opposed to female respondents.

It is possible to predispose the reluctance or refusal of respondents towards overseas tourism after COVID-19 universally into health risk, economic risk and opportunity loss. ${ }^{61}$ Accordingly, an outbreak of infectious diseases is one of the factors that contribute to the perceived health risk by tourists. In our study, we found that $30 \%$ of those who wish not to go travel overseas after COVID-19 cited the pandemic as the main reason. From an economic standpoint, an even larger proportion of respondents; 32\%, cited

\footnotetext{
${ }^{59}$ Yiwen Lin, Mihaela Kelemen, and Richard Tresidder, "Post-disaster Tourism: Building Resilience through Community-led Approaches in the Aftermath of the 2011 Disasters in Japan," Journal of Sustainable Tourism, Vol. 26, 2018, pp. 1766-1783.

${ }^{60}$ Stefan Gossling, Daniel Scott, and C. Michael Hall, "Pandemics, Tourism and Global Change: A Rapid Assessment of COVID-19," Journal of Sustainable Tourism, Vol. 29, 2021, pp. 1-20.

${ }^{61}$ Shih-Shuo Yeh, "Tourism Recovery Strategy against COVID-19 Pandemic," Tourism Recreation Research, 2020, available at: https://doi.org/10.1080/02508281.2020.1805933, accessed on 23 March, 2021.
} 
reasons directly related and/or leading to the issue. Of the 61 respondents, $26 \%$ mentioned financial constraints, while a further $16 \%$ remarked that they rather not go for overseas tourism specifying factors such as (the activity is a) poor use of money, work affairs or/and overseeing school-going children. In terms of general inclination towards traveling and/or tourism, we find that $18 \%$ of respondents expressed desire to support domestic tourism, and 7\% mentioned interest in visiting family members instead of tourism activities. This aligns with the opportunity loss stance, in which $\mathrm{Hu}$ (2011) suggested that it derived from the risk that tourists will miss the alternative when they commit to one tourism product or activity.

The survey found that overall, only $9 \%$ of respondents expressed genuine concern towards overseas tourism due to the threat of the current pandemic. The rest of the respondents involved are either keen on overseas tourism or plainly do not have interest (regardless of the pandemic). Of the respondents expressing interest towards overseas tourism, we found that the majority would rather delay such activities. $32 \%$ of respondents choose to go overseas for travel one year post COVID-19, 29\% said that they are willing to go within 6-12 months after overseas travel is allowed, 27\% choose within 3-6 months after overseas travel is allowed, and only $13 \%$ decided to go immediately once overseas travel is allowed.

\section{Table 3: Intention to Travel Abroad After the Pandemic Among Malaysians}

\begin{tabular}{|c|c|c|c|c|}
\hline \multicolumn{3}{|c|}{$\begin{array}{l}\text { Respondents' demography } \\
\qquad(\mathrm{n}=245)\end{array}$} & $\begin{array}{c}\text { Have intention } \\
\text { to go travel abroad ( } 75 \%)\end{array}$ & $\begin{array}{l}\text { Do not have intention to } \\
\text { go travel abroad (25\%) }\end{array}$ \\
\hline Age & $\begin{array}{l}25-29 \text { years old } \\
30-34 \text { years old } \\
35-39 \text { years old } \\
40-44 \text { years old } \\
45-49 \text { years old } \\
50-54 \text { years old } \\
55-59 \text { years old } \\
60 \text { years old and above }\end{array}$ & $\begin{array}{r}77(31 \%) \\
29(12 \%) \\
36(15 \%) \\
40(16 \%) \\
34(14 \%) \\
10(4 \%) \\
14(6 \%) \\
5(2 \%)\end{array}$ & $\begin{array}{l}74 \% \\
69 \% \\
78 \% \\
73 \% \\
74 \% \\
80 \% \\
93 \% \\
80 \%\end{array}$ & $\begin{array}{c}26 \% \\
31 \% \\
22 \% \\
27 \% \\
26 \% \\
20 \% \\
7 \% \\
20 \%\end{array}$ \\
\hline Gender & $\begin{array}{l}\text { Male } \\
\text { Female }\end{array}$ & $\begin{array}{r}81(33 \%) \\
164(67 \%)\end{array}$ & $\begin{array}{l}78 \% \\
74 \%\end{array}$ & $\begin{array}{l}22 \% \\
26 \%\end{array}$ \\
\hline $\begin{array}{l}\text { Marital } \\
\text { status }\end{array}$ & $\begin{array}{l}\text { Unmarried } \\
\text { Married with no children } \\
\text { Married with children }\end{array}$ & $\begin{array}{r}93(38 \%) \\
22(9 \%) \\
130(53 \%)\end{array}$ & $\begin{array}{l}82 \% \\
68 \% \\
72 \%\end{array}$ & $\begin{array}{l}18 \% \\
32 \% \\
28 \%\end{array}$ \\
\hline $\begin{array}{l}\text { Monthly } \\
\text { income }\end{array}$ & $\begin{array}{l}\text { RM0 - RM2,499 } \\
\text { RM2,500 - RM4,999 } \\
\text { RM5,000 - RM7,499 } \\
\text { RM7,500 - RM9,999 } \\
\text { RM10,000 and above }\end{array}$ & $\begin{array}{l}72(29 \%) \\
70(29 \%) \\
40(16 \%) \\
39(16 \%) \\
24(10 \%)\end{array}$ & $\begin{array}{l}64 \% \\
73 \% \\
68 \% \\
95 \% \\
96 \%\end{array}$ & $\begin{array}{c}36 \% \\
27 \% \\
32 \% \\
5 \% \\
4 \%\end{array}$ \\
\hline
\end{tabular}

Source: Results of Survey

Of the 184 respondents expressing interest towards overseas travel, the majority chose Japan and the Middle East as potential destinations. The percentage of respondents who mentioned Japan and the Middle East as their travel destination is $26 \%$ each. This is followed by South East Asia (22\%), Europe (9\%), South Korea (9\%), Australia (4\%), New Zealand (4\%), and America (1\%). $75 \%$ of the 48 choosing Middle East travel actually expressed interest specifically directed towards Mecca and Medina, with the 
remaining 25\% choosing either Turkey or the United Arab Emirates. Taking these fractions into consideration, it is found that Japan far exceeds other countries as a desired destination by Malaysian tourists post COVID-19.

Of the 48 respondents choosing to visit Japan, a majority (40\%) would prospectively do it a year after the pandemic ends, $29 \%$ would do so within 6-12 months after overseas travel is allowed, $17 \%$ choose within 3-6 months after overseas travel is allowed, and 15\% would go immediately once overseas travel is allowed. Not much disparity is observed between prospective first-time visitors and repeat visitors, with the numbers standing at $44 \%$ and $56 \%$ respectively.

As to the motivation behind their interest to visit Japan post-pandemic, the collected responses exhibit balanced numbers when comparing push and pull factors. In terms of push factors, the most prominent is personal visitation towards either a friend or/and family member with the next factor being a longing towards the environment in Japan which is especially noteworthy amongst respondents who have visited the island country before. The next factors would be to increase knowledge in terms of language and culture, to realize a dream and finally to have a vacation. On the subject of pull factor, the most notable is related to culture and environment. Most respondents cited the politeness and discipline of the Japanese society generated an attraction for them to visit the country. The next pull factor is the beautiful sceneries in Japan, followed by the elements of convenience and safety that Japan exudes.

Based on the case study conducted among Malaysians above, we may observe that alleviating inbound tourism to Japan is attainable or perhaps even a genuine prospect. Furthermore, since disaster due to epidemic is characterized by little or no impact on infrastructure and no long-term risk to tourists after the event has finished, ${ }^{62}$ there is arguably a clearer route to recuperation back to original or bettering prepandemic circumstances, as opposed to the amount of recovery efforts required back from an earthquake for instance. As long as service providers can offer services that increase confidence amongst prospective visitors that safety is of their utmost priority, it is believed that declining tourist numbers can be adequately overcome. In the case of COVID-19 however, the concern is not from one party where it spreads from locals to visitors. Instead, it also involves the concern that incoming visitors will potentially spread the unwanted viruses. Therefore, countermeasures that aim to restore travelers' confidence alone would not be sufficient to revive the mobility of inbound tourism in Japan.

In comparison with previous crises such as earthquakes and the H1N1 outbreak, the COVID-19 pandemic had an arguably greater impact as tourism activities were halted for more than a year. In this regard, tourism stakeholders in Japan can view this as an opportunity by benefitting from the sentiment of longing that potential tourists possess especially those who have previously visited Japan. As advocated by $\mathrm{Wu}$ (2014), tourists with more travel experience to Japan might perceive lesser risk as compared to those who have never visited the country. Taking nostalgia and sentiment of longing into account for example, travel packages with the arrangement of "previously visited locations" on offer may be attractive to tourists. At the same time, the idea of "different" may also appeal to potential tourists. That is, for tourism stakeholders to offer novel experiences that are refreshing opposites from the dreadful experience of more than a year cooped up inside one's own house and immediate surroundings. As economy is an important factor, meticulous consideration needs to be taken on the cost that potential tourists may be borne with especially as the pandemic has taken a significant economic toll on many.

On the part of the visitors, of utmost importance would be to be mindful of their own safety and health as there would arguably not be much in the way of economic risk and opportunity loss once they commit to visit Japan. Tour organizers can yet add value and further provide the sense of security by

\footnotetext{
${ }^{62}$ Jaume Rosselló, Susanne Becken, and Maria Santana-Gallego, "The Effects of Natural Disasters on International Tourism: A Global Analysis," Tourism Management, Vol. 79, 2020, available at: https://doi.org/10.1016/j.tourman.2020.104080, accessed on 23 March, 2021.
} 
stating and reminding visitors of existing standard operating procedures as well as issuing items of safety and health geared towards tourism that double up as souvenirs such as themed face masks, gloves, and hand sanitizer bottles.

\section{CONCLUSION}

History has shown how Japan has overcome the challenges it has faced. In looking at tourism as an economic activity, Japan will arguably yet again rise to face this challenge brought about by the current pandemic. It is only human nature to want to avoid threat, but over the years and in facing many a crisis, Japan has always sought out ways and strategies in which the perceived risks or/and threats of natural disasters and virus outbreaks pale in comparison to the allure it has towards inbound tourists. While it has always been a popular destination, Japan is also desirable for tourists due to several other factors such as convenience and safety. If and when there is a form of guarantee against the inconvenience of contracting COVID-19 and hence the perceived safety against it, tourism may well thrive again. Needless to say, it is an important industry not only to Japan but multiple other countries as well.

Being separated for almost two years, Japan needs to know how to satisfy the longing of foreign tourists for it. Hinging on perceived risks as well as push and pull factors of tourists from various nations, an impactful strategy must be adopted by Japan to nurture its inbound tourism back to health. In short, while attractions are important for tourism development, it is not enough to be a necessary condition for the success of a tourist destination because: "no safety, no tourism". ${ }^{63}$ However, a look at the experience of the Japanese in handling matters when natural disasters or disease outbreaks occurred in the past as well as the general appetite in Malaysian society for tourism to the island nation, it will be foolish to bet against Japan succeeding yet again.

\footnotetext{
${ }^{63}$ Haiyan Ma et al., "Safety or Travel: Which Is More Important? The Impact of Disaster Events on Tourism," Sustainability,
} Vol. 12, No. 7, 2020, available at: doi:10.3390/su12073038, accessed on 23 March, 2021. 


\section{REFERENCES}

A F Fithriyah et al., "Tourists' Attitude Affecting Consumption Behavior for Sustainable Satoyama Tourism: A Comparison between Domestic and International Tourists," IOP Conference Series: Earth and Environmental Science, Vol. 501, 2020, available at: https://iopscience.iop.org/article/10.1088/17551315/501/1/012030, accessed on 23 March, 2021.

Aaron Tkaczynski, Hayato Nagai, and Sharyn R Rundle-Thiele, "Australian Students' Activity Preferences, Perceived Physical Risk and Interest in Vacationing in Japan," Journal of Vacation Marketing, Vol. 24, No. 4, 2017, pp. 355-370.

Akira Soshiroda, "Inbound Tourism Policies in Japan from 1859 to 2003," Annals of Tourism Research, Vol. 32, No. 4, 2005, pp. 1100-1107.

Aliperti Giuseppe, and Ana Maria Cruz, "Risk Communication to Tourists: Towards the Definition of a Research Agenda for a More Effective Disaster Preparedness in Japan," Almatourism, Vol. 9, No. 17, 2018, pp. 1-12

Anh Thi Nguyen, “Japan's Inbound Tourism Boom: Lessons for Its Post-COVID-19 Revival," IMF Working Papers, Vol. 20, No. 169, 2020, pp. 1-19

Carolin Funck, "The Innovative Potential of Inbound Tourism in Japan for Destination Development - A Case Study of Hida Takayama,” Contemporary Japan, Vol. 24, No. 2, 2012, pp. 121-147.

Catherine Cheung, Miki Takashima, Hyungjung (Helen) Choi, et al., "The Impact of COVID-19 Pandemic on the Psychological Needs of Tourists: Implications for the Travel and Tourism Industry," Journal of Travel \& Tourism Marketing, Vol. 38, No. 2, 2021, pp. 155-166.

Centre for Aviation (CAPA), Airports in North-East Japan Affected by Earthquake and Tsunami: Airline Responses - UPDATE 1, CAPA, 13 March, 2011, available at: https://centreforaviation.com/analysis/reports/airports-in-north-east-japan-affected-by-earthquake-andtsunami-airline-responses---update-1-47679, accessed on 23 March, 2021.

Centre for Aviation (CAPA), Japan Crisis Has Major Impact on Regional Travel and Tourism Flows, CAPA, 25 March, 2011, available at: https://centreforaviation.com/analysis/reports/japan-crisis-hasmajor-impact-on-regional-travel-and-tourism-flows-48553, accessed on 23 March, 2021.

Chan Chung-Shing, Kazuo Nozu, and Qinrou Zhou, "Tourism Stakeholder Perspective for DisasterManagement Process and Resilience: The Case of the 2018 Hokkaido Eastern Iburi Earthquake in Japan," Sustainability, Vol. 12, No. 19, 2020, pp. 1-19

David Beirman, Making It Safe: Tourism after Japan's Earthquake, The Conversation, 22 February, 2021, available at: https://theconversation.com/making-it-safe-tourism-after-japans-earthquake-5691, accessed on 23 March, 2021 
Elaine Chiao Yang, and Vikneswaran Nair, "Tourism at Risk: A Review of Risk and Perceived Risk in Tourism," Asia-Pacific Journal of Innovation in Hospitality and Tourism, Vol. 3, No. 2, 2014, pp. 239259.

Fangnan Cui et al., “An Overview of Tourism Risk Perception,” Natural Hazards, Vol. 82, No. 1, 2016, pp. 643-658.

Gagan Deep Sharma, Asha Thomas, and Justin Paul, "Reviving Tourism Industry Post-COVID-19: A Resilience-Based Framework," Tourism Management Perspectives, Vol. 37, January 2012, available at: https://doi.org/10.1016/j.tmp.2020.100786, accessed on 23 March, 2021.

Girish Prayag and Chris Ryan, “The Relationship between the 'Push' and 'Pull' Factors of a Tourist Destination: The Role of Nationality - an Analytical Qualitative Research Approach," Current Issues in Tourism, Vol. 14, No. 2, 2011, pp. 121-143.

H Nishiura et al., "Modelling Potential Responses to Severe Acute Respiratory Syndrome in Japan: The Role of Initial Attack Size, Precaution, and Quarantine," Journal of Epidemiology \& Community Health, Vol. 58, No. 3, 2004, pp. 186-191.

Haiyan Ma et al., "Safety or Travel: Which Is More Important? The Impact of Disaster Events on Tourism," Sustainability, Vol. 12, No. 7, 2020, available at: doi:10.3390/su12073038, accessed on 23 March, 2021.

Isabell Handler, "The Impact of the Fukushima Disaster on Japan's Travel Image: An Exploratory Study on Taiwanese Travelers," Journal of Hospitality and Tourism Management, Vol. 27, June, 2016, pp. 1217.

Jaume Rosselló, Susanne Becken, and Maria Santana-Gallego, "The Effects of Natural Disasters on International Tourism: A Global Analysis," Tourism Management, Vol. 79, 2020, available at: https://doi.org/10.1016/j.tourman.2020.104080, accessed on 23 March, 2021.

Jeonghee Noh, and Christine Vogt. "Modelling Information Use, Image, and Perceived Risk with Intentions to Travel to East Asia." Current Issues in Tourism 16, No. 5, 2013, pp. 455-76.

Jing $\mathrm{Xu}$, and Pimtong Tavitiyaman, "Why Do Hong Kong Young People like to Visit Japan? An Exploratory Study," Advances in Hospitality and Tourism Research, Vol. 4, No. 1, 2016, pp. 17-25.

Kaila Imada, Japan Updates Its Quarantine Rules and Extends Entry Restrictions, Time Out Tokyo, 16 February, 2021, available at: https://www.timeout.com/tokyo/news/japan-extends-travel-restrictions-andrevises-quarantine-rules-020521-020521, accessed on 23 March, 2021.

Lingling Wu, “An Analysis of Inbound Tourist Behavior after the Great East Japan Earthquake,” In 13th Global Forum on Tourism Statistics, 2014. 
Lisa Schnirring, Japan Has 1st Novel Coronavirus Case; China Reports Another Death, Center for Infectious Disease Research and Policy (CIDRAP), 16 January, 2020, avalable at: https://www.cidrap.umn.edu/news-perspective/2020/01/japan-has-1st-novel-coronavirus-case-chinareports-another-death, accessed on 23 March, 2021.

Liu Jiangyong. Japan Issues Multiple-Entry Visas to Chinese Tourists, People's Daily Online, 20 July, 2011, available at: http://en.people.cn/90001/90776/90883/7446588.html, accessed on 23 March, 2021.

Martin Enserink, WHO Declares Official End to H1N1 'Swine Flu' Pandemic, Science, 11 December, 2017, available at: https://www.sciencemag.org/news/2010/08/who-declares-official-end-h1n1-swineflu-pandemic, accessed on 23 March, 2021

Naciye Guliz Ugur, and Adem Akbiyik, "Impacts of COVID-19 on Global Tourism Industry: A CrossRegional Comparison," Tourism Management Perspectives, Vol. 36, October 2020, available at: https://doi.org/10.1016/j.tmp.2020.100744, accessed on 23 March, 2021.

Nicholas D Kristof, An Ancient City Hopes to Reassure Tourists That It Is Safe to Visit, The New York Times, 24 January, 1995, available at: https://www.nytimes.com/1995/01/24/world/quake-japan-kyotoancient-city-hopes-reassure-tourists-that-it-safe-visit.html, accessed on 23 March, 2021.

Oxford Analytica, "Pandemic Damage to Japan's Tourism Sector will Linger," Expert Briefings- Oxford Analytica, 2020, available at: https://doi.org/10.1108/OXAN-DB255140, accessed on 23 March, 2021.

Seongseop Kim, Bruce Prideaux, and Dallen Timothy, "Factors Affecting Bilateral Chinese and Japanese Travel," Annals of Tourism Research, Vol. 61, 2016, pp. 80-95.

Shih-Shuo Yeh, "Tourism Recovery Strategy against COVID-19 Pandemic," Tourism Recreation Research, 2020, available at: https://doi.org/10.1080/02508281.2020.1805933, accessed on 23 March, 2021.

Shimaditya Nuraeni, Arlavianyssa Pradiva Arru, and Santi Novani, "Understanding Consumer DecisionMaking in Tourism Sector: Conjoint Analysis," Procedia - Social and Behavioral Sciences, Vol. 169, 2015, pp. 312-317.

Stathis Polyzos, Aristeidis Samitas, and Anastasia Ef. Spyridou, "Tourism Demands and the COVID-19 Pandemic: An LSTM Approac," Tourism Recreation Research, 2020, available at: https://doi.org/10.1080/02508281.2020.1777053, accessed on 23 March, 2021.

Stefan Gossling, Daniel Scott, and C. Michael Hall, "Pandemics, Tourism and Global Change: A Rapid Assessment of COVID-19," Journal of Sustainable Tourism, Vol. 29, 2021, pp. 1-20.

Sung Hee Park, Chi-Ming Hsieh, and Choong-Ki Lee, "Examining Chinese College Students' Intention to Travel to Japan Using the Extended Theory of Planned Behavior: Testing Destination Image and the Mediating Role of Travel Constraints," Journal of Travel \& Tourism Marketing, Vol. 34, No. 1, 2016, pp. $113-131$. 
Tadayuki Hara, "Perception of Language Barriers or Prior Visit Experience Affect Likelihood of Visiting a Country? Empirical Analysis of Residents in the United States of America about Japan as a Tourism Destination," Waseda Global Forum, Vol. 10, 2013, pp. 391-407.

Tracey Dickson, and Sara Dolnicar, "No Risk, No Fun: The Role of Perceived Risk in Adventure Tourism," Research Online, 2004, available at: http://ro.uow.edu.au/commpapers/246, accessed on 23 March, 2021.

Valeriya Shapoval et al., "Data Mining in Tourism Data Analysis: Inbound Visitors to Japan," Journal of Travel Research Vol. 57, No. 3, 2017, pp. 310-323.

Xin (Cathy) Jin, Mingya Qu, and Jigang Bao, "Impact of Crisis Events on Chinese Outbound Tourist Flow: A Framework for Post-Events Growth,” Tourism Management, Vol. 74, 2019, pp. 334-344.

Xinran You et al., "A Cross-Cultural Comparison of Travel Push and Pull Factors," International Journal of Hospitality \& Tourism Administration, Vol. 1, No. 2, 2000, pp. 1-26.

Yiwen Lin, Mihaela Kelemen, and Richard Tresidder, "Post-disaster Tourism: Building Resilience through Community-led Approaches in the Aftermath of the 2011 Disasters in Japan," Journal of Sustainable Tourism, Vol. 26, 2018, pp. 1766-1783.

Yoshitaka Ishikawa, "Impact of the Economic Crisis on Human Mobility in Japan: A Preliminary Note," Belgeo, No. 3-4, 2011, pp. 129-148. 